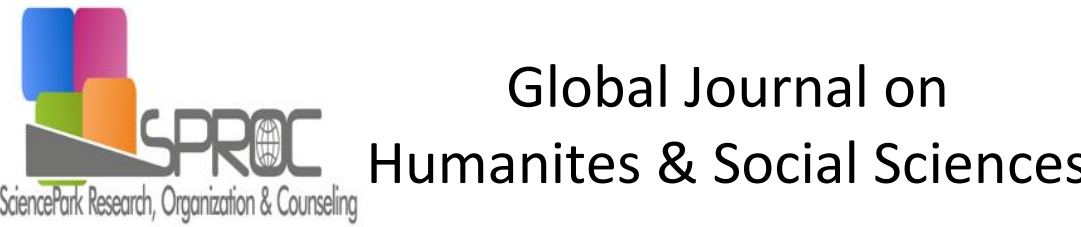

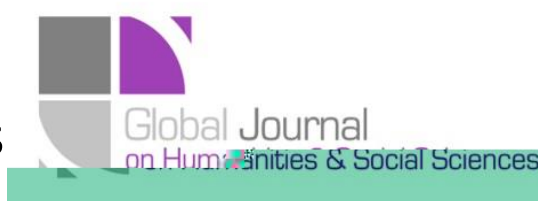

Issue 4 (2016) 76-83

Selected Paper of 4rd World Congress of Administrative and Political Sciences, (APDOL-2015)

28-29 November 2014,University of Barcelona, Barcelona, Spain.

\section{A policy analysis study: Family medicine}

Cagdas Erkan Akyurek*, Faculty of Health Sciences, Healthcare Management Department, Ankara Unıversity, Altındag - Ankara 06340, Turkey.

Esin Mutluer, Faculty of Health Sciences, Healthcare Management Department, Ankara Unıversity, Altındağ Ankara 06340, Turkey.

Deniz Tugay Arslan, Faculty of Health Sciences, Healthcare Management Department, Ankara Unıversity, Altındag- Ankara 06340, Turkey.

\section{Suggested Citation:}

Akyurek, C.E., Mutluer, E. \& Arslan D.T. (2016). A policy analysis study: Family medicine, Global Journal on Humanites \& Social Sciences. [Online]. 04, pp 76-83. Available from: http://sproc.org/ojs/index.php/pntsbs

Received June 17, 2015; revised August 11, 2015; accepted October 17, 2015.

Selection and peer review under responsibility of Prof. Dr. Andreea lluzia IACOB

(C)2016 SciencePark Research, Organization \& Counseling. All rights reserved.

\begin{abstract}
Every single government which accepts the reality that "healthy nations comprise of healthy citizens" choose to make reforms in the healthcare systems that they are responsible to govern, in the frame of policies they have adopted. The most extensive action in the last 20 year of Turkish Republic in this context is Health Transformation Programme (HTP). "Family Physician Model" is one the significant steps through the purpose of abolishing the obstacles in front of access to health care services, which is one of the main aims of HTP.

In this study, it is aimed to present a critical perspective by revealing the main reasons to adopt family medicine as a fundamental political choice, taking a glance at the history of family medicine, examining the changes created by family medicine and giving place to the views of shareholders.
\end{abstract}

Keywords: family physician, healthcare, health policies, primary health care services, policy analysis

*ADDRESS FOR CORRESPONDENCE: Cagdas Erkan, Akyurek, Faculty of Health Sciences, Healthcare Management Department, Ankara Unıversity, Altındag - Ankara 06340, Turkey. E-mail address: erkanakyurek52@hotmail.com /

Tel.: +90-312-319-1450 


\section{Introduction}

The concept of health was defined as "the state of complete physical, mental and social well-being and not merely the absence of disease or infirmity" with the signature of the representatives of 61 states at the International Health Conference organized by World Health Organization (WHO) in 1946 (WHO, 1946). The most distinctive characteristic of this definition is the holistic view of the status of being healthy. The same holistic perspective was revealed by a leader exactly 24 years earlier before this official definition:

"The health and robustness of Turkish citizenship who are imposed various vital duties of revolution and revolutionism are always be an accentuated national concern. This is because Republic requires intellectually, socially, scientifically and physically strong and high-level protectors."

Mustafa Kemal ATATÜRK (1922)

The path to healthy individual and healthy society as commonly agreed upon depends on wellfunctioning and well-managed healthcare systems. With the purpose of this "well managed healthcare system" various states from different parts of the world embark on reformation movements starting from different parts of their healthcare system. In the first step, the fundamental purpose of these reformation movements is to remove the barriers before the access to healthcare services and to enable the citizens apply to get services from the service providers meeting without an obstacle. In the second step, the basic concerns of the states reached to a certain extent in removing the barriers before the access to healthcare services during the reformation process is quality and the costs of the services.

Turkey, now is at a certain level in the first step with Health Transformation Program (HTP) which contains the most extensive reformation movement of the last 20 years and started to put the concerns of the second step forefront. In the context of increasing the level of access to healthcare services, how the healthcare services are managed plays an important role in the first step. Family Medicine implementation which is one of the basic components of HTP is attributed important responsibilities as it is in many countries.

The main reasons for the transition to Family Medicine in Turkey are officially listed as; not being able to provide infrastructure and employment conditions to fulfil the universal necessities of health, centralised organisation structure, excessive bureaucracy, civil servants lacking responsibility, inequalities in providing and accessing healthcare services, not being able to spread the healthcare services along the country equally and unsatisfactory and not promotive payment to the healthcare service providers (http://ailehekimligi.gov.tr, a.d.: December $21^{\text {th }}, 2014$ ).

\section{Purpose of Study}

The purpose of this study is to reveal the main reasons behind the Family Medicine implementation as a political choice, look at its historical evolution, analyse the changes that the implementation brings and assert a critical perspective by sharing the opinions of respective parties of the issue. By the nature of methodology, mainly criticisms against the system are concentrated on. 


\section{Methodology}

In order to make the study qualified as a "Policy Analysis" and carry out it in a systematic way, "Health Policy Analysis Checklist" has been utilised. This checklist is a guide which includes the issues and/or approaches that have to be taken into consideration during a policy analysis process. Mostly during policy analysis processes, differences between theory and practices are observed. Since all the headings identified in the checklist are not appropriate for every project, the ones related with the content of this study are included. This necessity is also emphasized in the instructions part of the checklist.

Theoretical basis of the checklist considerably depends on a model developed by Bardach, yet additionally the points directly related to implementation, evaluation and management have been taken into consideration. On the other side, the checklist is developed through the references of healthcare service providers and finance organisations.

\section{What is Family Physician?}

Family physician is defined as family medicine specialist or medical specialist(s) who receives trainings determined by the Ministry of Health and works full-time and is liable to provide individualoriented preventive healthcare services with primary diagnosis and curative healthcare services without any discrimination on grounds of age, sex and disease in a certain place comprehensively and persistently and/or in at-home visits if necessary (Family Medicine Implementation Directive, 2013). The fundamental principles that family medicine relies on are listed as management and coordination of primary healthcare services, people oriented healthcare service, developing and using authentic problem-solving skills, comprehensive approach, family and general trends by European Academy of Teachers in General Practice (EURACT) operating in coordination with World Organization National Colleges, Academies (WONCA) (EURACT, 2005).

Family medicine was brought up in 1923 for the first time by British doctor Francis Peabody. He emphasised that as a result of overspecialization patients do not get enough support and that is why another medical speciality providing a comprehensive and individual healthcare service is a necessity (Tüzün and Kaya, 2009).

\subsection{The History of Family Medicine in Turkey}

Three periods in development of family medicine in Turkey can be referred. The first period is between 1983-1993. Family medicine was stated in "Bylaw on Medical Specialty" dated July $5^{\text {th }}, 1983$. Alongside the initiation of specialization training on family medicine in state hospitals and getting the first specialists doctors ready, in 1984 the first family medicine department was founded on paper and in 1985 it actively started in the teaching hospitals affiliated to the Ministry of Health in Ankara, İstanbul and İzmir. In 1990 the interns who received family medicine training established "Association of Family Physicians" (AFP) in Ankara and in 1993 the first "Scientific Congress of Family Medicine" was realised in İstanbul. Again in this period, "Journal of Family Practice", which was a first in scientific platform, started to be published with the efforts of İstanbul branch of the association (Ünlüoğlu and Paycl, 2004). In one way, this period is expressed as the period when the first steps to family medicine were taken.

During the period of 1993-2002, primary initiatives for healthcare services, "Draft Law on Family Medicine, draft curriculum for family medicine and organisation of the first trainings for the trainers 
were realised by the General Coordinatorship of Health Project in the Ministry of Health in 1993 while the implementation oriented initiatives were commenced in the province of Bilecik as the pilot area.

On July $16^{\text {th }}, 1993$ by the decision numbered 12547 of the Council of Higher Education (CHE) the establishment of Department of Family Medicine in medical schools was accepted. On September $17^{\text {th }}$, 1993, Department of Family Medicine was founded in Trakya University and the residency training in the department started. In 1993 the first "National Congress of Family Medicine" was realised in İstanbul. Moreover, "Family Medicine Application Centres" were opened in Ankara in 1994 and in Adana, Bursa and Izmir in 1996 by the "General Directorate of Primary Healthcare" and "Branch of Family Medicine" in the Ministry of Health. Since 1993, National Congress of Family Medicine has been regularly organised in every two years and in the years when Congress are not organised "Family Medicine Days" are organised. In April 1995, General Coordinatorship of Health Project in the Ministry of Health published the "Family Medicine Residency Curriculum". In 1996, the title of associate professorship in the family medicine department was conferred on for the first time in Turkey. Also, the Journal of Family Practice has been published on a regular basis as refereed journal since 1997. On March $2^{\text {nd }}, 1998$, AFP acquired the right of use "Turkey" in its name and as Turkish Association of Family Physicians (TAFP) it gained the right to represent Turkey in the world. In 2001, for the first time in Turkey a family medicine specialist was elected to one of the Board of Directors in WONCA. Besides, TAFP's membership of WONCA and WONCA Europe began in 2003. This period can be qualified as a period when the developments in academic aspect arose. The titles of associate professorship and professorship were conferred on in this period for the first time (Söyleyici, 2010).

The third period in development process of family medicine in Turkey started with the main objectives released under the heading of "Health for Everyone" in "Urgent Action Plan" in 2002 and the announcement of them under the name of the "Health Transformation Program" in 2003 and has come until today.

Family Medicine Pilot Implementation Act no. 5258 was published in the Official Gazette dated November 24th, 2004 and numbered 25650. Then respectively, Directive about Family Medicine Pilot Implementation was published in the Official Gazette dated July $6^{\text {th }}, 2005$ and numbered 25867, and the Directive Concerning the Conditions of Contract and Reimbursement to the Personnel of the Ministry of Health in the Context of Family Medicine Pilot Implementation was published in the Official Gazette dated August $12^{\text {th }}, 2005$ and numbered 25904. Afterwards, aforementioned second directive was repealed with the Legislation on Contract and Payment Principles and Procedures to be Made to the Personnel Who Were Employed by The Ministry of Health Within the Scope of the Family Medicine Implementation which was published in the Official Gazette dated December $30^{\text {th }}, 2010$ and numbered 27801. On September $15^{\text {th }}, 2005$ family medicine pilot implementation was launched in the province of Düzce and still family medicine model is implemented for primary healthcare services in 81 provinces.

Family medicine system has been carried out with the pilot legislation since 2004. It is interesting that even on December $13^{\text {th }}, 2010$ when the family medicine system spread all over Turkey there was still no basic law existing. While in 2010, 1,983,428,000 TL was expended on the family medicine expenses (purchase of goods and services) from the budget, budget proposal concerning the purchase of goods and services within the scope of family medicine expenses to the Grand National Assembly of Turkey (TGNA) for 2011 was 3,984,277,200 TL (101\% increase) (Belek, 2012).

\section{The Views of Shareholders about Family Medicine}

\subsection{Views in the Grand National Assembly of Turkey Records}

Sami Tandoğdu, Republican People's Party Province of Ordu Deputy, in his speech made on November $10^{\text {th }}, 2004$ expressed that in the coming years family medicine can create major problems 
in the healthcare system and family medicine implementation in Bulgaria since 1999 has made the people suffered and claimed that only the states in which the family medicine was being well practised were selected to do research on.

Mustafa Özyurt, Republican People's Party Province of Bursa Deputy, in his speech made on November $24^{\text {th }}, 2004$ in TGNA criticised that the essence of draft law on family medicine was constituted upon per person who are registered. He reminded the answer of Prof. Abel Smith when he was requested to assess Turkey's motivation for transition to family medicine as he was in Turkey as a guest. In his answer, he stated that Turkey was not able to give free healthcare to everyone with family medicine; since labour force in healthcare sector was not equally dispersed across the country, Turkey should not carry family medicine into practice (TGNA, 2004a).

Uğur Neşşar, Republican People's Party Province of Denizli Deputy, in his speech made on November $24^{\text {th }}, 2004$ in TGNA expressed that healthcare systems based upon the premium payments per patient increase the health expenditures and lead family physicians more to curative medicine rather than preventive medicine for this reason in the countries where family medicine is implemented severe fiscal problems arises (TGNA, 2004b).

Zeheyir Amber, Motherland Party Province of Hatay Deputy, in his speech made on April $19^{\text {th }}, 2006$ in TGNA mentioned that promoting and increasing competition by turning patients into customer, community health centres into family medicine enterprises and hospitals into health enterprises will not improve the quality and efficiency in healthcare services; on the contrary, leaving healthcare service in cruel and inhumane hands of free market with customer-oriented service understanding and marketization will create major social problems and cause individual sufferings.

\subsection{Turkish Medical Association's (TMA) View}

In 2013, Turkish Medical Association made their assessment of family medicine as a system in their own publication Journal of Community and Physician (TMA, 2013):

Family physician is an artificial physician model which is based upon insurance systems.

Family medicine is not a discipline which comes out as a result of societal necessities and scientific developments, but an artificially constituted branch by the economic systems targeting to gain more income from health.

Organisation model of family physician is not population-oriented. She/he does not deals with the people in a certain geographical region but only the ones who choose herself/himself and are registered in her/his centres.

Family physician is an individually working physician. Family medicine does not comply with team mentality. Family physician works in competition and tries to register as much as patients in her/his list.

Individual-oriented preventive service understanding is wrong. Preventive services are provided regarding the social utility. Family medicine does not embrace a universal understanding and individual-oriented preventive healthcare approach can cause irreparable traumas within the society.

"Right to choose physician" and "one physician for each family" do not reflect the reality.

Positive competition is not a matter of discussion.

Family medicine is a very expensive system. Having considered the fact that every family physician has to open her/his own clinic and furnish it and unnecessary overlapping of medical apparatus like x-ray and USG machines and the traffic of patients between the physicians and 
laboratories, it would not be a surprise that there is an increase in expenses. It is obvious that family medicine system is a profitable one rather than a cheap one.

High wages for physicians are not realistic. The purpose is not paying physician, but enabling them to earn their own money within free market conditions and removing healthcare from public service.

\subsection{Views of Unions, Associations and Confederations}

In a statement made by

${ }^{*}$ affiliated with Türkiye Kamu-Sen ${ }^{\dagger}$ it was stated that the employees in family medicine implementation are employed on contractual basis and this type of employment abolishes job security as abolishing medical staff's right to be appointed (http://www.medimagazin.com.tr/haber.php?id=48939\&q=aile\%20hekimliği, a.d.: December $20^{\text {th }}$, 2014).

According to

Health Sector Council's statement the transition from general practice to family medicine needs to be eased and promoted. Inefficiency of existing physical places in metropolitans will be more visible in the case of transition to family medicine. For this reason, needs of physical places where family physicians provide treatment service should be fulfilled. The legislation concerning the patient referral procedure by the family physicians should be revised in accordance with more fair and rational scoring criteria and a referral chain should be formed (http://www.medimagazin.com.tr/haber.php?id= $\left.46687 \& q=a i l e h e k i m l i g ̆ i, ~ a . d .: ~ M a r c h ~ 20^{\text {th }}, 2014\right)$.

ff $\quad l \quad l$ has the opinion that family medicine is not suitable for Turkey's socio-economic structure, because even in the countries with strong economies and high-level of income, this model is being hardly conducted. It is because this system is based upon giving individual-oriented curative healthcare services rather than preventive healthcare services and the cost of these services is quite high. Family medicine is expressed as a paid model unlike community health centres and it means that not everyone can benefit from the service and epidemics will increase (http://www.referansgazetesi.com/haber.aspx?HBR KOD=56527, a.d.: March 10 ${ }^{\text {th }}, 2014$ ).

In 2006 TUPEHSS published a family medicine leaflet and according to that leaflet they objected to family medicine since it demolishes preventive healthcare services, team mentality, increases the workload and drudgery of medical staff due to its individual-oriented approach, is a costly model that increases unnecessary use of medical technology, brings flexibility in working conditions and grounds on contractual employment (TUPEHSS, 2006).

ff ff pays attention to the lack of family physician in Turkey and the family medicine regulation is compared to "speed up train". In TCEA report, it is revealed that if "there is one family physician for every 800 people in developed countries", it means Turkey currently needs 90 thousand family physicians. The study claims that practising physicians are to be employed as family physician and in that case it will not be "family medicine" but "speed up family medicine" (http://www.memurlar.net/haber/12098/, a.d.: March 10" 2014).

According to

, the family medicine pilot programmes implemented by Ministry of Health should absolutely include dentistry services. In this way, what is done wrong, right or incompetent can be seen during the implementation and how to provide dentistry services

\footnotetext{
* Trade Union of Public Employees in Health Sector affiliated with Türkiye Kamu-Sen.

${ }^{\dagger}$ Turkish Confederation of Public Employees Trade Unions.
} 
can be decided ((http://www.tdb.org.tr/tdb/sayfa4.php?s1=1\&ac=1\&es=2\&sayfa=45\&grup=7, a.d.: April $14^{\text {th }}$, 2014).

According to a report prepared for the ff $\quad l \quad l$, family medicine is based upon physician-oriented service rather than team-oriented services. Moreover, it embraces the service principle of healthcare only to the ones applied, accessed in healthcare organisations rather than the service principle of healthcare to anyone, in anywhere, any time. In the report, it is expressed that when the pilot implementations are observed it can be said that family medicine is favouring relatively developed urban settlements rather than creating a solution for poor people who needs healthcare services more and under these conditions it is not possible to expect an increase in the level of general health of the society. It is also noted in the report that the supervision of the family medicine services will be difficult as such in the coordination between the institutions and organisations. SPHS criticises the family medicine model in action due to the fact that it focuses on treatment more. Besides, SPHS emphasizes that family physicians in this model are employed on a contractual basis with the Ministry of Health and the main drawback of this program is the problem of privatisation in the health sector.

\section{Conclusion and Recommendations}

Today, it is a commonly held reality that well-functioning healthcare system needs a wellestablished primary healthcare service. Family medicine which is not necessarily a new implementation is put into operation in various countries and a political choice with successful and unsuccessful outcomes. The success of the implementation is affected by various factors including the characteristics of that country's healthcare system, the preferences and inflexible beliefs of the society. Therefore, during the decision-making process for family medicine, an integrative approach has to be pursued by taking the characteristics of the given environment into account as well. This is because, family medicine itself cannot be the only cause of success or failure of the implementation.

Further studies on family medicine should mostly focus on the examination of various studies done by now with qualitative data rather than making policy analysis or policy examination. Accuracy of the negative and positive judgements towards the family medicine implementation should be concretely asserted.

\section{References}

Family Medicine Implementation Directive (FMID), Ministry of Health, First Part, General Provisions, First Part, Definitions, Article 3, May 25 2013.

Family Medicine, Turkish Public Health Institution, Ministry of Health, (Access) Retrieved December $21^{\text {st }}, 2014$ from: $\quad$ http://www.ailehekimligi.gov.tr/index.php?option=com content\&view=article\&id=152:ailehekimikimdir\&catid=56:aile-hekimlii-nedir\&ttemid=190,

Belek, i. (2012). Transformation in Health, Imperialist Attack against the People's Health (Sağlıkta Dönüşüm, Halkın Sağlığına Emperyalist Saldırı), Yazılama Publishing, İstanbul.s.83.

WHO (1946) Definition of Health, International Health Conference, June $19^{\text {th }}-22^{\text {nd }}, 1946$, Official Records of the WHO, 2, 100.

European Academy of Teachers in General Practice (EURACT), 2005, The European Definition of General Practice / Family Medicine, Short Version.

Retrieved March 20 2014 From: http://www.medimagazin.com.tr/haber.php?id=46687\&q=ailehekimliği , Access date: March $20^{\text {th }}, 2014$

Retrieved March 10 ${ }^{\text {th }}, 2014$ from: http://www.medimagazin.com.tr/haber.php?id=48939\&q=aile\%20hekimliği "Claims for Family Medicine by Force" (Access Date: March $10^{\text {th }}$, 2014). 
Akyurek, C.E., Mutluer, E. \& Arslan D.T. (2016). A policy analysis study: Family medicine, Global Journal on Humanites \& Social Sciences. [Online]. 04, pp 76-83. Available from: http://sproc.org/ojs/index.php/pntsbs

Retrieved March 10 $0^{\text {th }}, 2014$ from: http://www.memurlar.net/haber/12098/

Retrieved March 10 ${ }^{\text {th }}, 2014$ from: http://www.referansgazetesi.com/haber.aspx?HBR KOD $=56527$

Retrieved March 10 $10^{\text {th }}, 2014$ from: http://www.tdb.org.tr/tdb/sayfa4.php?s1=1\&ac=1\&es=2\&sayfa=45\&grup=7

Öztek, Z. (2007) "Healthcare Services in Turkey: Problems and Solution Offers" (Türkiye'de Sağlık Hizmetleri sorunlar ve Çözüm Önerileri)

Retrieved April 15 ${ }^{\text {th }}, 2014$ from: http://www.hasuder.org.tr/doc/ailehekimligi rapor.doc

SES (2006). Family Medicine Leaflet (Aile Hekimliği Broşürü) Retrieved April 16 ${ }^{\text {th }}, 2014$ from: http://ses.org.tr/images/dokuman/sesailehekimligi.pdf

Söyleyici, T. (2010). The Patient Satisfaction Level in the Family Medicine

Practice: Denizli Case" (Aile Hekimliği Uygulamasında Hasta Memnuniyet Düzeyi: Denizli Uygulaması), Pamukkale University, Institute of Social Sciences, Political Science and Public Administration, Master's Thesis, Denizli.

TGNA (2004a). General Assembly Records $22^{\text {nd }}$ Period $3^{\text {rd }}$ Legislation Year $16^{\text {th }}$ Session November $10^{\text {th }}, 2004$.

TGNA (2004b). General Assembly Records $22^{\text {nd }}$ Period $3^{\text {rd }}$ Legislation Year $21^{\text {th }}$ Session November $24^{\text {th }}, 2004$.

TGNA (2006). General Assembly Records $22^{\text {nd }}$ Period $4^{\text {th }}$ Legislation Tear $90^{\text {th }}$ Session April $19^{\text {th }}, 2006$.

Tüzün, S., \& Çiğdem Apaydın Kaya, "History of family medicine as a specialisation branch" (Uzmanlık dalı olarak aile hekimliğinin tarihi), Retrieved November $28^{\text {th }}, 2014$ from: http://www.tahud.org.tr/guncel/asistandagarcigi/uzmanlik-dali-olarak-aile-hekimliginin-tarihi/11

Ünluoglu, i.,, \& Paycl, S. (2004). Family Medicine in the World and in Turkey (Dünya'da ve Türkiye'de Aile Hekimliği), Ministry of Health.

Weiner, J. (2005). Health Policy Analysis Checklist: For the Development, Selection and Assessment of Program Policies Within Health Care Organizations, Johns Hopkins Bloomberg School of Public Health, Introduction to Health Policy, Version, August $8^{\text {th }}, 2005$. 